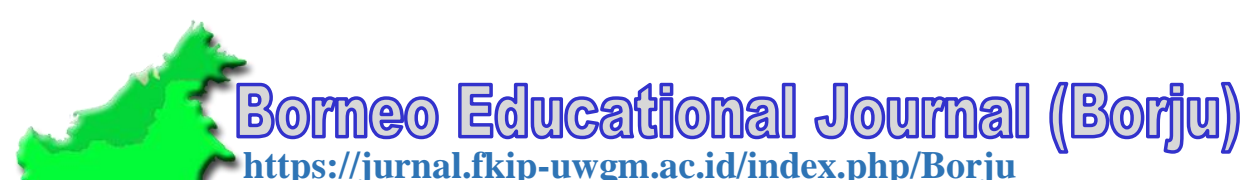

https://jurnal.fkip-uwgm.ac.id/index.php/Borju

E-ISSN: 2655-9323

February 2020, Vol.02 No.01

\title{
The Challenges in Translating Indonesian Abstract Text to English
}

\section{Jumiati ${ }^{1}$, Godefridus Bali $\mathbf{G}^{2}$}

Universitas Widya Gama Mahakam, Indonesia ${ }^{1,2}$

Email Correspondence: ijum8598@gmail.com

\begin{abstract}
The translation is a tool to communicate for people who have different languages. The translation makes it easier for them to understand what others say and get more information from the other languages, especially on the abstract that will help the researcher so that it is easy to get the desired information. In the abstract, their much information that gains for the researcher. Therefore, the researcher is dedicated to studying the challenges of translating.

This study aims to know the challenges in translating Indonesian abstract text to English faced by eight-semester students' of the English Department at Widya Gama Mahakam Samarinda. The subject used of the study was $8^{\text {th }}$ semester students in the English department of Widya Gama Mahakam Samarinda. There are five students as participants. The research design to use is qualitative. To collect the data, the researcher uses interview guidelines. The interview result showed that lexicon, grammar, element semantic, and translation style were the challenges in translating Indonesian abstract text to English.
\end{abstract}

Keywords: Challenges; Translating; Abstract Text

\begin{tabular}{|c|c|c|}
\hline DOI & $:$ & https://doi.org/10.24903/bej.v2i1.625 \\
\hline Received & : & January 2020 \\
\hline Accepted & : & February 2020 \\
\hline Published & : & February 2020 \\
\hline $\begin{array}{l}\text { Copyright and } \\
\text { License }\end{array}$ & : & $\begin{array}{l}\text { Authors retain copyright and grant the journal right of first publication with the } \\
\text { work simultaneously licensed under a Creative Commons Attribution } \mathbf{4 . 0} \\
\text { International License that allows others to share the work with an acknowledgement of } \\
\text { the work's authorship and initial publication in this journal. } \\
\text { cC }\end{array}$ \\
\hline
\end{tabular}




\section{INTRODUCTION}

Since the Second World War [1], various fields such as politics, academia, international business, and globalization have been linked to the increase in the use of the internet and media in communication, using English as a lingua franca (ELF) besides, English is used in contact as one of the foreign languages [2] English is used in Indonesia as a foreign language studied by learners. In addition, Indonesian students have low proficiency in English lessons [3]. Moreover, English was used as an international communication language [3]. In Indonesia, English was used as a foreign language learned by students. Besides, students in Indonesia have low proficiency in English lessons [3]. Therefore, they need to translate the meaning from Indonesian to English or vice versa. It is to make it easier for them to understand the information obtained from the source language.

The most critical knowledge in translating is about grammatical structure. It is considered essential to change the meaning of the source-language text to transferring in targetlanguage text. However, it will affect making the translation more challenging because students must find out the words or sentences equivalent to the context of the text. In process translation, the students will have trouble because lacking knowledge possessed. Therefore, this will be one of the challenges. In this study, the researcher would be done to describe challenges on abstract translation faced by eight-semester students' English department majors at Widya Gama Mahakam Samarinda. Furthermore, based on the problems of the study above, the objective of the study is to know challenges in translating Indonesian abstract text to English of the English Department in Widya Gama Mahakam Samarinda.

\section{METHODOLOGY}

This study uses a qualitative approach and case study as a research design. Qualitative research is understanding related phenomena experienced by the subject such as behavior, perception, motivation, actions, etc., in the form of words described in a specific context [4]. According to [5] a case study focuses on situation and event (phenomena) to understand the specific problem. In this study, the researcher focuses on context related to the subject's perception of the challenge in translating Indonesian abstract text to English based on experienced. Therefore, in the researcher used case study as a research design.

In other words, The subject who was involved in this research was $8^{\text {th }}$-semester students' of the English department. However, this study was conducted with interviews as research instruments, and this activity, it has some steps to collect the data; In collecting data, the researcher will take the following steps. The steps are as follows: 
a. Select and recruit the respondent (purposes sampling)

In this step, the researcher determines the participants who suitable the criteria in this study.

b. Draft the interview guidelines

To make the interview the data become more accessible, the researcher made a question

In analyzing the data, the researcher used models from [6]. The authors' data analysis activities consist of data reduction, data display, and data conclusion drawing or verification. That after the researcher has the result in collecting the data, the researcher did data analysis with the three steps of models [6].

\section{FINDINGS}

In translation, the translator's purpose is more than interpreting and transferring a message from the source language to the target language. Many meanings can be obtained in transfer the words because of ambiguity; it has other meanings in a different context of the sentence. Furthermore, the researcher found there are several challenges in translating abstract text to use by the researcher. The challenges in translating abstract faced by $8^{\text {th }}$-semester students included lexicon, grammar, element semantic, and style of translating, which each present as follows:

\subsection{Lexicon}

The lexicon challenge is useful vocabulary mastery between the two languages to translate and must own by translators. Furthermore, the respondent in translating Indonesian abstract text to English more often faces this challenge. However, they also explained that they try to find more general words or synonyms for difficult or unfamiliar words to resolve the challenge.

\subsection{Grammar}

Grammar is also the challenge in translating Indonesian abstract text to English faced by the students. The students explained that grammar is a challenge in translating. However, in this study researcher found that the subject more difficult to take and replaced some verb words in translation.

\subsection{Element Semantic}

In element semantic, the translator faced a challenge in understanding the context contained in the source language. However, the subject challenged in translation and made the subject misunderstanding the context. One of the subject's results said; the challenge she experienced, between the target text with the original text, has a meaning that does not match. 


\subsection{Style of Translating}

In this result, the subject challenges in to replace the word into translation. The subject more did not know how they can change some verb in the text. Furthermore, this caused the subject did not know how to change or replace the word in context

\section{DISCUSSION}

In this study, some research was confirmed by a previous study, and some theory was proved the result. The four of the result the subject's challenges were impacted their translation skill, and the subject has an impact on they understood the meaning of the context. As [7] states, in this study, to analyze lexicon item (word) of the source language needs to know students' because sometimes the word has a different meaning. Moreover, the students must have good knowledge about vocabulary related to both languages to more accessible for them to determine the use of a suitable word, so the meaning does not change the context in a sentence. When the students' difficulty in both languages, the more difficult it is to determine the fit meaning in the target language. Moreover, they must try hard to find words that are suitable to use.

\section{CONCLUSION}

The challenges more faced by $8^{\text {th }}$-semester students in the English department at Widya Gama Mahakam Samarinda University translate Indonesian abstract text to English related to the lexicon problem, especially in determining the vocabulary in one word, many meaning can find. It is difficult for the translator to adjust so that it does not have an ambiguous meaning of the sentence in the target language. Besides, grammar is also a challenge faced by one of the students. They need to correct that the grammar in the target language to source language is in accordance. Another challenge is semantic; the translator does not understand the context of the sentence. It makes the translator is confused about how to translate the sentence from the original text (source language). The translator becomes a bridge that will convey meaning to the target language without change the form of context text in the source language. Semantic, which uses to find the target language, not to bring up different meanings from context. The translator must understand what is translating. The various challenges students face need to improve and upgrade new vocabulary their unknown meaning and find the synonym of the words. The students also need to pay attention to the segmentation of grammatical. 


\section{REFERENCES}

[1] E. Rowley-Jolivet, "English as a Lingua Franca in research articles: the SciELF corpus," ASp, vol. 71, pp. 145-158, 2017.

[2] A. Cogo and M. L. Pitzl, "English as a Lingua Franca," Int. J. Appl. Linguist., vol. 23, no. $3,2013$.

[3] A. Lie, "Education Policy and EFL Curriculum in Indonesia: Between the Commitment to Competence and the Quest for Higher Test Scores,” TEFLIN J., 2007.

[4] L. J. Moleong, Metodologi Penelitian Kualitatif. Bandung: PT Remaja Rosdakarya, 2016.

[5] L. R. Gay, G. E. Mills, and P. Airasian, Educational Research: Competencies for Analysis and Applications, 10th ed. Boston: Pearson, 2012.

[6] M. B. Milles, M. A. Huberman, and J. Saldana, Qualitative Data Analysis A methods Sourcebook Edition 3. 2014.

[7] E. Trimadona, "Some Difficulties in Translating Scientific Texts," vol. 1, no. 2, pp. 2 7, 2016. 